\title{
OCCURRENCE OF Scolytinae IN MANGROVE WITH IMPACT TRAP AND IN WOOD OF FIVE FOREST SPECIES
}

\author{
OCORRENCIA DE Scolytinae EM MANGUEZAL COM ARMADILHA DE IMPACTO \\ E NA MADEIRA DE CINCO ESPÉCIES FLORESTAIS
}

\section{Charles Oliveira da SILVA ${ }^{1}$; Henrique TREVISAN ${ }^{2}$; Thiago Sampaio de SOUZA ${ }^{3 *}$; Acacio Geraldo de CARVALHO ${ }^{2}$}

1. Postgraduate Program in Environmental Sciences and Forestry, Federal Rural University of Rio de Janeiro, Seropédica, RJ, Brazil; 2. Department of Forest Products, Institute of Forestry, Federal Rural University of Rio de Janeiro, Seropédica, RJ, Brazil; 3. Postgraduate

Program in Crop Science, Federal Rural University of Rio de Janeiro, Seropédica, RJ, Brazil. thiagosampaio.agro@gmail.com

\begin{abstract}
Scolytinae is a beetle group belonging to Order Coleoptera; these insects play an essential role in wood degradation in forest ecosystems, since they build galleries that enable substrate colonization by other saprophytic organisms, as well as nutrient cycling. Thus, the aim of the current study was to evaluate the occurrence of Scolytinae in the wood of 5 tree species exposed to mangrove environment, as well as to simultaneously survey Scolytinae specimens captured in ethanol-baited impact traps placed in the same environment. The study was carried out in a mangrove area located in Santa Cruz neighborhood - RJ. Five freshly-harvested Clitoria fairchildiana, Rhyzophora mangle, Corymbia citriodora, Melia azedarach and Eucalyptus pellita wood logs ( $1 \mathrm{~m}$ long and $5-10 \mathrm{~cm}$ diameter) were arranged perpendicular to the ground $(1 \mathrm{~m}$ above it) and spaced $30 \mathrm{~cm}$ away from each other. Five impact traps were set up $50 \mathrm{~m}$ away from each other, $1.3 \mathrm{~m}$ above the ground. Insects were collected for 5 months. One hundred and thirty (130) Scolytinae individuals (14 species in 2 genera) were recorded in the wood logs; the relative frequency (Fr) of the species comprised Xyleborus affinis (33.9\%) and Hypothenemus sp.4 (17.7\%), which represented $51.6 \%$ of the total number of captured individuals. Hypothenemus sp.6 specimens were not collected in ethanol-baited traps, but the wood of $C$. fairchildiana. E. pellita did not show insect infestation. The traps captured 798 individuals (24 species belonging to 8 genera); the frequency of $X$. affinis (25.3\%) and Hypothenemus eruditus (14.5\%) represented $39.8 \%$ of the total number of captured insects.
\end{abstract}

KEYWORDS: Coleoptera. Xylophagous. Forest Entomology. Mangrove.

\section{INTRODUCTION}

Insects belonging to the Order Coleoptera prevail in tropical environments; besides, they are mentioned as one of the most important pests in forest areas, since they play a key role in wood deterioration and, consequently, in nutrient cycling (GRAY, 1972). According to Berti Filho (1982), Scolytinae are one of the main agents triggering the deterioration of newly-felled wood.

Thus, scolytids (Coleoptera: Scolytinae) play a key role in wood degradation processes, since they drill galleries - for nesting and feeding purposes - in different tree parts, mainly in newlyfelled or weakened trees undergoing sap fermentation processes (SIMEONE, 1965; FURNISS; CAROLIN, 1977; GONÇALVES et al., 2014). In addition, they enable moisture to penetrate these perforations - phloeophagous species remain restricted to the bark of trees, whereas xylomycetophagous species go deep into the wood, which becomes a potential site for the development of fungi (symbiont or not). These fungi are responsible for accelerating the degradation of this substrate, which can lead to severe losses when the wood is used for commercial purposes (COULSON; LUND, 1973; FINDLAY, 1985). On the other hand, these insects play an important ecological role in assisting the nutrient cycling process. The wood could decompose much slower if it was not for the action of these Coleoptera, since galleries built by them enable the action of decomposers.

Thus, scolytids can be found in virtually all forest ecosystems, including in mangroves. However, this ecosystem has peculiar ecological features such as intermittent tidal regimes that could hinder the action of Scolytinae, since everyday salt water occupies sites that, on land, enable the action of organisms such as litter, fallen trunks and senescent shrubs. Given the reduced number of ecological Scolytinae niches, these organisms are not expected to be often found in mangroves in comparison to other forest environments. Despite the scarcity of research focused on elucidating this issue, some studies have reported that this group is abundant and acts in this ecosystem (GERÓNIMO- 
TORRES et al., 2015). So far, there is no research focused on addressing this issue in Brazil.

Accordingly, experiments conducted in Belize (Central America) have shown that living Rizophora mangle trees are attacked by several species of wood borers, including by Scolytinae larvae (FELLER; MATHIS, 1997). Jordal (2014) has reported that some Scolytinae species feed on, and develop in, roots of mangrove plants.

In light of the foregoing, the aim of the current study was to evaluate the occurrence of Scolytinae on the wood of five tree species exposed to mangrove environment, as well as to simultaneously survey scolytids captured in ethanolbaited impact traps placed in the same environment.

\section{MATERIAL AND METHODS}

The experiment was carried out in a mangrove area located in Santa Cruz neighborhood ( $22^{\circ} 5^{\prime}$ '39.85” S, $\left.43^{\circ} 46^{\prime} 12.89^{\prime} \mathrm{W}\right)$, Rio de Janeiro, from March 17 to July 28, 2011. According to Köppen's classification (1948), the climate in the area is Aw, i.e., rainy season in summer and dry season in winter. The annual rainfall reaches 2,230 $\mathrm{mm}$ and it is concentrated from November to April; the mean annual temperature is $24.7^{\circ} \mathrm{C}$.

The wood used in the experiment were from trees belonging to the species: Melia azedarach L. (for ray), Meliaceae; Clitoria fairchildiana R. A. Howard (sombreiro), Fabaceae; Eucalyptus pellita F. Muell (eucalyptus), Myrtaceae; Corymbia citriodora (Hook) K. D. Hill \& L. A. S. Johnson (eucalyptus), Myrtaceae; and Rhyzophora mangle L. (red mangrove), Rhizophoraceae. Specimens from the first four species were collected from trees grown on the campus of Federal Rural University of Rio de Janeiro (UFRRJ) in Seropédica-RJ, whereas the $R$. mangle specimen was collected at the site where the experiment was conducted.

Five wood $\operatorname{logs} 1 \mathrm{~m}$ long with diameter varying from 5.0 to $10.0 \mathrm{~cm}$ were used from the aforementioned forest species. Wood samples from each forest essence were arranged perpendicular to the ground, $1.0 \mathrm{~m}$ above it and spaced $30 \mathrm{~cm}$ away from each other, one day after they were collected from the forest species. They were supported by a wire stretched between two trees inside the mangrove to prevent the logs from being touched by water, even at full tide. The experimental design was based on completely randomized blocks separated from each other by five meters, with five repetitions.

Thirty days after the wood logs were exposed to the mangrove environment, 10 -cm-long sub-samples were collected from each investigated species with a pruning saw; this procedure was repeated every 15 days. These sub-samples were placed in transparent plastic bags (20 liters), sealed and taken to the Forest Entomology Laboratory of the Forest Products Department at UFRRJ (LEF/DPF/UFRRJ), where they were subdivided and Scolytinae individuals were collected.

Five ethanol-baited impact traps, model Carvalho-47 were also set up at the place where the experiment was carried out to attract and capture scolytids (CARVALHO, 1998). The traps were installed $1.3 \mathrm{~m}$ above the ground and spaced $50 \mathrm{~m}$ away from each other. Insects captured by the traps were collected on a weekly basis, when the ethanol was refilled. Captured insects were taken to LEF/DPF/UFRRJ in order to classify and quantify individuals belonging to subfamily Scolytinae. It was done to enable calculating the absolute and relative frequency, as well as to determine the incidence of these species.

Insects captured by the traps and the ones collected in the wood samples were sent to one expert for taxonomic identification purposes. The frequency of each Scolytinae species was calculated in both experiments, based on the ratio between the number of individuals from each species and the total number of collected individuals, multiplied by 100; results were expressed in percentage. The incidence of the two main Scolytinae species (higher Fr) collected through impact traps and wood subsamples were graphically represented.

The dominance of collected species was also analyzed; species whose frequency was higher than $1 / \mathrm{S}$ were categorized as dominant, whereas species whose frequency was lower than $1 / \mathrm{S}$ were categorized as non-dominant; wherein $\mathrm{S}$ is the total number of species in the community (Richness). As for their constancy, species found in more than 50\% of samples were classified as constant, the ones found in $25-50 \%$ of samples were accessory, and those found in less than $25 \%$ of samples were accidental (URAMOTO; WALDER; ZUCCHI, 2005). These individuals were also grouped based on their eating habits, according to the classification by Wood (1982).

\section{RESULTS AND DISCUSSION}

One hundred and thirty (130) individuals belonging to subfamily Scolytinae were found the wood; they were distributed in 14 species belonging to genera Hypothenemus and Xyleborus. The impact traps captured 798 individuals belonging to 24 species, which were distributed in 8 genera (Table 
1). Similar result was reported by Laidlaw et al. (2003), who found that pheromone-baited funnel traps captured twice as many Scolytinae individuals as the wood from exposed trees at the same time and place as the aforementioned traps.

Table 1. Absolute (Fa) and relative (Fr) frequencies, dominance (dominants $(\mathrm{D})$ and non-dominants $(\mathrm{N}))$ and constancy of bark and ambrosia beetles species captured in mangrove environment, in traps (Tr.) and in the wood (Woo.) of 4 forest species, from March to July 2011.

\begin{tabular}{|c|c|c|c|c|c|c|c|c|c|}
\hline \multirow{2}{*}{ Species } & \multicolumn{2}{|c|}{ Wood } & \multicolumn{2}{|c|}{ Trap } & \multicolumn{2}{|c|}{ Dominance } & \multicolumn{2}{|c|}{ Constancy } & \multirow{2}{*}{ Habit $^{*}$} \\
\hline & $\mathrm{Fa}$ & $\mathrm{Fr}$ & $\mathrm{Fa}$ & $\mathrm{Fr}$ & Woo. & Tr. & Woo. & Tr. & \\
\hline Xyleborus affinis Eichhoff & 44 & 33.9 & 202 & 25.3 & $\mathrm{D}$ & $\mathrm{D}$ & Accessory & Constant & 1 \\
\hline Hypothenemus sp.4 & 23 & 17.7 & 78 & 9.8 & $\mathrm{D}$ & $\mathrm{D}$ & Constant & Constant & $2 ; 3$ \\
\hline Hypothenemus sp.13 & 18 & 13.8 & 13 & 1.6 & D & $\mathrm{N}$ & Accessory & Accidental & $2 ; 3$ \\
\hline Hypothenemus sp.7 & 14 & 10.8 & 76 & 9.5 & $\mathrm{D}$ & $\mathrm{D}$ & Accessory & Constant & $2 ; 3$ \\
\hline Hypothenemus eruditus Westwood & 6 & 4.6 & 116 & 14.5 & $\mathrm{D}$ & $\mathrm{D}$ & Accidental & Constant & $2 ; 3$ \\
\hline Hypothenemus sp.10 & 5 & 3.8 & 8 & 1 & $\mathrm{~N}$ & $\mathrm{~N}$ & Accidental & Accidental & $2 ; 3$ \\
\hline Hypotheneтus obscurus (Fabricius) & 4 & 3.1 & 43 & 5.4 & $\mathrm{~N}$ & $\mathrm{D}$ & Accessory & Constant & $2 ; 3$ \\
\hline Hypothenemus sp.6 & 4 & 3.1 & 0 & 0 & $\mathrm{~N}$ & - & Accidental & - & $2 ; 3$ \\
\hline Xyleborus ferrugineus (Fabricius) & 4 & 3.1 & 2 & 0.3 & $\mathrm{~N}$ & $\mathrm{~N}$ & Accessory & Accidental & 1 \\
\hline Hypothenemus sp.3 & 2 & 1.5 & 6 & 0.7 & $\mathrm{~N}$ & $\mathrm{~N}$ & Accidental & Accidental & $2 ; 3$ \\
\hline Hypothenemus sp.11 & 2 & 1.5 & 2 & 0.3 & $\mathrm{~N}$ & $\mathrm{~N}$ & Accidental & Accidental & $2 ; 3$ \\
\hline Hypothenemus sp.9 & 2 & 1.5 & 4 & 0.5 & $\mathrm{~N}$ & $\mathrm{~N}$ & Accidental & Accidental & $2 ; 3$ \\
\hline Hypothenemus sp.12 & 1 & 0.8 & 3 & 0.4 & $\mathrm{~N}$ & $\mathrm{~N}$ & Accidental & Accidental & $2 ; 3$ \\
\hline Hypothenemus sp.5 & 1 & 0.8 & 2 & 0.3 & $\mathrm{~N}$ & $\mathrm{~N}$ & Accidental & Accidental & $2 ; 3$ \\
\hline Ambrosiodmus opimus (Wood) & 0 & 0 & 54 & 6.8 & - & $\mathrm{D}$ & - & Constant & 1 \\
\hline Hypothenemus sp.2 & 0 & 0 & 50 & 6.3 & - & $\mathrm{D}$ & - & Constant & $2 ; 3$ \\
\hline Cryptocarenus heveae (Hagedorn) & 0 & 0 & 36 & 4.5 & - & $\mathrm{D}$ & - & Constant & $1 ; 3$ \\
\hline Tricolus subincisuralis Schedl & 0 & 0 & 26 & 3.2 & - & $\mathrm{N}$ & - & Constant & 1 \\
\hline Hypothenemus sp.1 & 0 & 0 & 21 & 2.6 & - & $\mathrm{N}$ & - & Constant & $2 ; 3$ \\
\hline Hypothenemus sp.8 & 0 & 0 & 19 & 2.4 & - & $\mathrm{N}$ & - & Constant & $2 ; 3$ \\
\hline Premnobius cavipennis Eichhoff & 0 & 0 & 17 & 2.1 & - & $\mathrm{N}$ & - & Constant & 1 \\
\hline Ambrosiodmus obliquus (LeConte) & 0 & 0 & 14 & 1.8 & - & $\mathrm{N}$ & - & Accidental & 1 \\
\hline Cryptocarenus seriatus Eggers & 0 & 0 & 4 & 0.5 & - & $\mathrm{N}$ & - & Accidental & $1 ; 3$ \\
\hline Microcorthylus minimus Schedl & 0 & 0 & 1 & 0.1 & - & $\mathrm{N}$ & - & Accidental & 1 \\
\hline Pityophthorus sp.1 & 0 & 0 & 1 & 0.1 & - & $\mathrm{N}$ & - & Accidental & $1 ; 3$ \\
\hline
\end{tabular}

1= Xylomycetophagous; 2=Herbiphagous; 3= Myelophagous.

Of the 25 species identified in the mangrove, only Hypothenemus sp.6 was not captured in the traps; it was only recorded in the wood C. fairchildiana specimens. Although both collection methods were capable of successfully capturing insect species Hypothenemus sp.13 and Xyleborus ferrugineus (Fabricius), the number of insects captured by the wood logs was larger than that of insects captured by the traps (Table 1). Both species were captured in C. fairchildiana wood logs; however, Hypothenemus sp.13 was also captured in the wood of $R$. mangle specimens, whereas $X$. ferrugineus was captured in the wood of $M$. azedarach specimens (Table 2).

The time pattern of the incidence of bark and ambrosia beetles species captured in traps was not similar to that of species directly collected in wood samples (Figure 1). The explanation for this outcome may be associated with specific wood conditions, mainly with moisture and extractive fermentation (LUNZ; CARVALHO, 2002), which have changed depending on the time of exposure in the field and influenced the incidence of insects. The same did not apply to traps, since they enabled constant insect-attraction conditions throughout the experimental period.

The species most often captured in traps were Xyleborus affinis Eichhoff and Hypothenemus eruditus Westwood, which accounted for $39.8 \%$ of captured individuals. These species also accounted for $38.5 \%$ of individuals captured in wood logs; therefore, they were categorized as dominant species in the mangrove, based on the two collection strategies (Table 1). 
Table 2. Absolute (Fa) and relative (Fr) frequencies of Scolytinae species collected in the wood of 4 forest species exposed to mangrove environment, from March to July 2011.

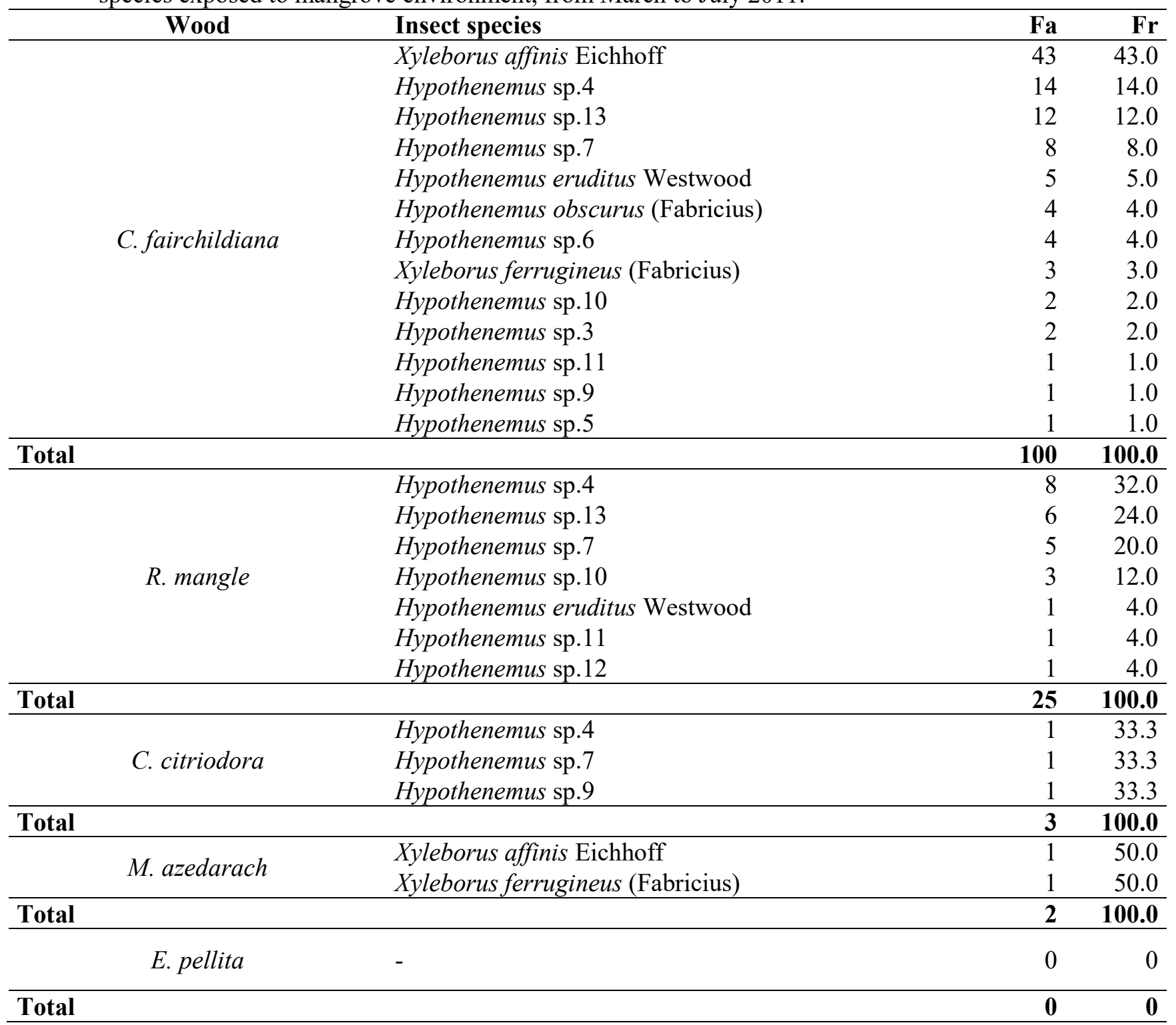

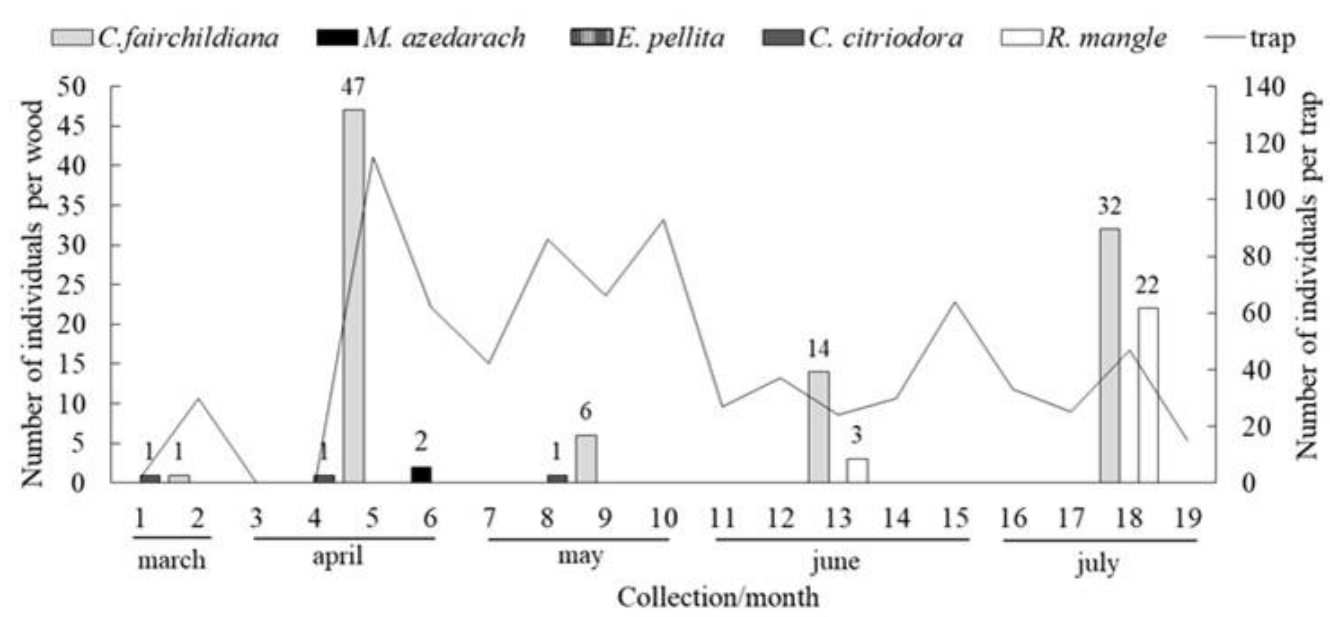

Figure 1. Number of Scolytinae individuals captured in ethanol-baited traps and in the newly-felled wood of 5 forest species exposed to mangrove environment for 5 collection months. 
Species $H$. eruditus is often found in tropical regions (PEDROSA-MACEDO; SCHÖNHERR, 1985; FLECHTMANN et al., 1995) and Xyleborus is the richest genus within subfamily Scolytinae (KUMAR; CHANDRA, 1977) and one of the most abundant in Brazil (FLECHTMANN et al., 1995). Gerónimo-Torres et al. (2015) have used impact traps to investigate the incidence of bark and ambrosia beetles in mangroves in Mexico; they recorded the incidence of 22 Scolytinae species, as well as of $X$. affinis and $H$. eruditus. However, species Xyleborus volvulus (Fabricius) recorded the highest relative frequency and it was followed by $X$. ferrugineus and $X$. affinis. $H$. eruditus was the eighth most collected species (GERÓNIMOTORRES et al., 2015). Impact traps were used by Pereira (2006) to collect insects in a Pinus spp. forest stand in Paraná State (Brazil), who recorded significant abundance of $X$. ferrugineus.

Besides being the most common species in genus Xylodromus (WOOD, 1982), X. affinis is one of the species most often captured in traps due to high tropism in the presence of ethanol (PEDROSAMACEDO; SCHÖNHERR, 1985; ABREU; FONSECA; MARQUES, 1997). Thus, the mangrove environment in Rio de Janeiro State can contribute to significant incidence of $X$. affinis due to its great humidity and temperature conditions for most of the year (Table 1). This hypothesis was corroborated by Beaver (1976), who emphasized that the hotter and wetter the environment, the better the $X$. affinis adaptation to it.

Several surveys carried out in Brazil have highlighted the significant abundance of $H$. eruditus captured in ethanol-baited traps. Among these surveys, one finds the ones carried out on land in Pinus spp. (MARQUES, 1989; PEREIRA, 2006); in Pinus and Eucalyptus (FLECHTMANN; OTTATI; BERISFORD, 2001); in Hevea brasiliensis (Willd. ex A.Juss.) Müll.Arg. (rubber tree) (DALL'OGLIO; PERES FILHO, 1997); in Acacia mearnsii De Willd. (MURARI, 2005); forest formations (SILVA, 2000); in native forest in Southern Brazil (PELENTIR, 2007); and native forest (CARVALHO; ROCHA; LUNZ, 1996). However, Andreiv and Müller (1998) have stated that the incidence of $H$. eruditus is associated with modified environments and that this species is rarely found in native forests.

Xyleborus affinis and Hypothenemus sp.4 were the species most often found in the wood logs used in the current study; they accounted for $51.6 \%$ of the collected individuals. They also accounted for $35.1 \%$ of individuals captured in traps; consequently, they were categorized as dominant species in the mangrove environment (Table 1). Species belonging to genus Xyleborus are among the most destructive groups; they present significant aggressiveness and can damage any part of freshlyharvested or standing trees, or even healthy hosts; besides, they can cause damages such as small holes with black marks associated with xylophagous fungi (CHANDRA, 1981; WOOD, 1982). On the other hand, genus Hypothenemus is herbiphagous and myelophagous; individuals belonging to this genus feed on the marrow of small branches, as well as on tree branches, shrubs, lianas, fruits or seeds, and on other plant materials (WOOD, 1977, 1982). However, based on the eating habits of Scolytinae species captured in the mangrove environment, 12\% of them were xylomycetophagous/myelophagous, $28 \%$ were exclusively xylomycetophagous and $60 \%$ were herbiphagous/myelophagous. These findings differ from the ones recorded by Meuer et al. (2013) in Pantanal of Cáceres, Mato Grosso State, Brazil, where $99 \%$ of the captured species were xylomycetophagous. According to Wood (1982), the increased incidence of xylomycetophagous scolytids is associated with food resource and host availability. Thus, it is possible assuming that the low botanical diversity found in the mangrove environment, as well as other ecological attributes inherent to this ecosystem such as intermittent tide regimes, are factors that hinder the incidence of scolytids, mainly of species xylomycetophagous.

Although species $X$. affinis recorded one of the highest incidences in the wood $\operatorname{logs}(33.9 \%)$ exposed to the mangrove environment, genus Hypothenemus recorded the largest total number of individuals; it presented $63 \%$ representativeness with 12 different species. Species $X$. affinis recorded the highest incidence $(25.3 \%)$ of insects captured in traps; however, the group of species belonging to genus Hypothenemus accounted for $55.3 \%$ of the total number of captured insects (Table 1). Rocha et al. (2011) have analyzed the incidence of Scolytinae in Eucalyptus camaldulensis reforestation system in Mato Grosso State; based on their results, species $H$. eruditus and $X$. affinis were more often found in the dry season, whereas $X$. ferrugineus prevailed in the rainy season. Dorval et al. (2017) conducted a study in a closed-forest savanna in Cuiabá County (MT) and observed higher incidence of species $X$. affinis than of $X$. ferrugineus in all seasons.

Melia azedarach wood logs were only colonized by scolytids belonging to genus Xyleborus schollitans, whereas $C$. citriodora and $R$. mangle wood logs were only colonized by species belonging to genus Hypothenemus (Table 2). This feature can be associated with specific volatile 
substances from each forest species; these substances can attract or repel Scolytinae. Therefore, it is possible assuming that some bark and ambrosia beetles genera may show preference for certain wood types, when they can choose, as seen in the experimental situation simulated in the current study. In addition, some insects may have been more attracted to ethanol than other species, or some wood species used in the test were not attractive to some insect species in the mangrove environment. Furthermore, it is worth highlighting that E. pellita wood logs did not present infestation by Scolytinae (Table 2), as well as that species Hypothenemus sp.6 was not captured in traps.

Accordingly, Marques (1989) has compared Scolytinae populations captured in ethanol-baited traps set up in Pinus plantation to the ones directly collected in the wood of this tree species and did not find equivalent populations between the two capturing methods. There was higher incidence of $H$. eruditus in traps, whereas wood logs presented higher incidence of $X$. ferrugineus individuals and no representative of species $H$. eruditus. The aforementioned study diverges from findings in the current study, since $H$. eruditus individuals were collected in traps (Table 1) and in the wood of $C$. fairchildiana and $R$. mangle, whereas species $X$. ferrugineus was captured in the wood of $C$. fairchildiana and M. azedarach (Table 2).

Clitoria fairchildiana wood logs recorded the highest total incidence of Scolytinae $(76.9 \%)$, and they were followed by $R$. mangle $(19.2 \%), C$. citriodora $(2.3 \%)$ and $M$. azedarach $(1.6 \%)$. No individuals were found in E. pellita wood logs. The considerably larger number of scolytids in $C$. fairchildiana can be mainly explained by the incidence of species $X$. affinis, which accounted for $33.9 \%$ of the total number of insects collected in all wood logs (Table 1). Abreu (1992), Abreu and Bandeira (1992) and Abreu et al. (2002) have evaluated the incidence of Scolytinae in the Amazon region and also found a larger number of $X$. affinis individuals infesting different wood species.

However, Lunz and Carvalho (2002) adoted a methodology equivalent to the one applied in the current study in order to evaluate the incidence of Scolytinae in the wood of six botanical species grown in an Atlantic Forest fragment. Results showed that H. eruditus and Coccotrypes palmarum Eggers were the scolytids most often found in the wood of $C$. fairchildiana. These findings were different from the ones observed for this wood species in the current study (Table 2). Lunz and Carvalho (2002) have found 473 Scolytinae individuals in $C$. fairchildiana samples, whereas the current study, which adopted equivalent sample effort, found only 100 individuals in this wood species. Therefore, the comparison between findings by Lunz and Carvalho (2002) and those in the current study may generate the hypothesis that mangroves present peculiar ecological features that can enable conditions capable of hindering the action of Scolytinae insects in wood. In order to corroborate this hypothesis, it is worth highlighting that E. pellita wood logs exposed to the mangrove environment were not infested by Scolytinae insects. This outcome differs from the one recorded by Dorval et al. (2007), who evaluated bark and ambrosia beetles infestations in the wood of 4 different eucalypt species grown in terrestrial environment and found that E. pellita was one of the species most infested by these insects. Therefore, the ecological features of the mangrove environment investigated in the current study could explain the lack of infestation and the low action of Scolytinae insects in the wood of $E$. pellita and $C$. fairchildiana, respectively, in comparison to the studies by de Dorval et al. (2007) and Lunz and Carvalho (2002).

Among the species captured in the wood logs, only Hypothenemus sp. 12 was not found in $C$. fairchildiana however was exclusively captured in $R$. mangle. Thus, it is possible suggesting that genus Hypothenemus prefers the wood of $R$. mangle species, since no other Scolytinae genus was found in it. Importantly, there are endemic and specific species of mangrove trees such as Coccotrypes rhizophorae (Hopkins) that, according to Sousa, Quek and Mitchell (2003), are exclusively found in trees grown in this environment, such as R. mangle, Rhizophora mucronata Lam and Nephelium lappaceum L.; however, this scolytid was not yet recorded in Brazil (WOOD, 2007). In addition, according to the aforementioned author, Scolytinae species Scolytopsis puncticollis Blandford is distributed throughout the Americas and uses the tree species Laguncularia racemosa (L.) C.F. Gaertn (white mangrove) as host; however, it was not captured in the current experiment.

The time incidence of $X$. affinis, $H$. eruditus and $H$. sp.4 was compared between the two collection strategies. Results showed that the population pattern differed between wood and traps throughout the experiment. However, there was similar incidence of $X$. affinis in both collection methods. The population peak of this species was recorded in April, both in traps and in wood logs. However, the incidence of this species in wood logs decreased considerably in May (Figure 2). 


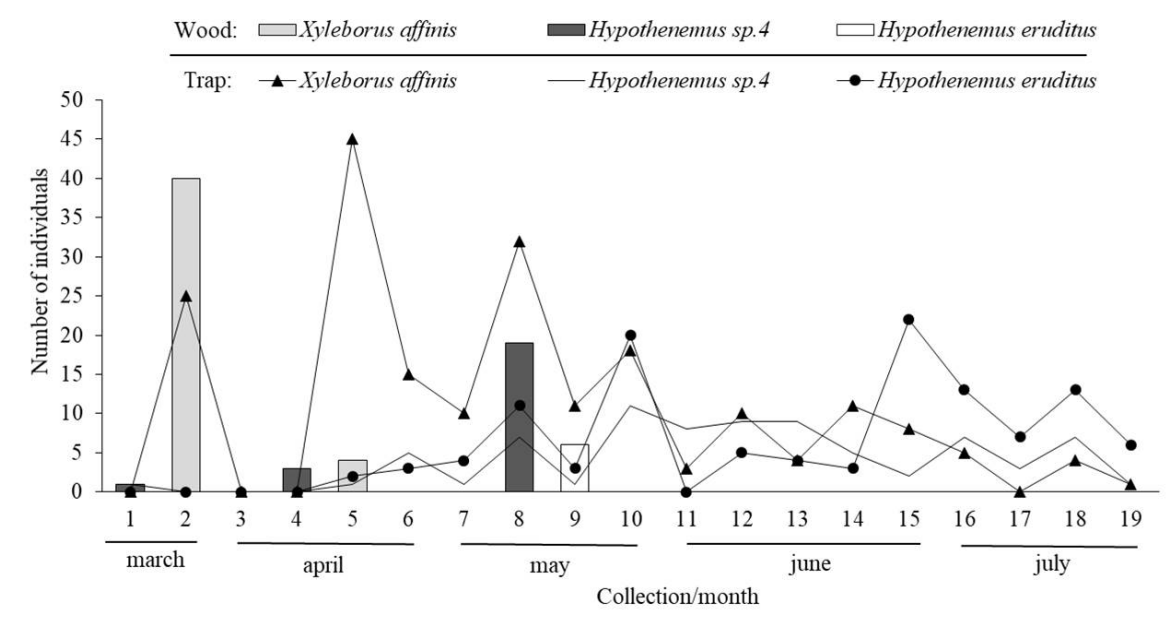

Figure 2. Incidence of the two most captured species in wood samples and in ethanol-baited traps placed in mangrove environment.

Such decrease may be explained by the fact that wood does not present the proper conditions to enable $X$. affinis development, i.e., the longer this substrate remained exposed in the field, the higher the loss of moisture to the environment. Since this scolytid present xylomycetophagous behavior, moisture is a vital condition to enable its action in the wood (WOOD, 1982). Besides this hypothesis, it is worth emphasizing that $X$. affinis was no longer captured in the wood logs from June on; it was only captured by traps until the end of the experimental period (Figure 2). This outcome has evidenced that $X$. affinis individuals remained in the environment; however, the wood logs, were probably no longer attractive to them.

On the other hand, individuals belonging to genus Hypothenemus were captured in traps throughout the experimental period, as seen in $X$. affinis. However, the incidence of individuals belonging to this genus in the wood logs was only observed from May on, which corresponded to half of the experimental period (Figure 2). This outcome suggests that individuals belonging to genus Hypothenemus demand less wood moisture because they do not present xylomycetophagous behavior (ABREU et al., 2002). Thus, it could explain the capture of this group in the wood logs from the middle to the end of the experimental period, i.e., when the substrate presented lower moisture level than that of the beginning of the experiment.

With respect to the constancy of species captured in traps, $50 \%$ were categorized as constant, whereas $50 \%$ were categorized as accidental species. As for the constancy of species captured in wood logs, $H$. sp.4 was the only constant species $(7.7 \%)$ in the mangrove environment, whereas the other species were categorized as accessory (38.5\%) and accidental (53.8\%). Species $H$. sp.4, X. affinis and $H$. eruditus, which were constantly captured in traps, presented constant, accessory and accidental distribution in the wood logs, respectively (Table 1).

\section{CONCLUSION}

Scolytinae is a group distributed in mangrove environment in Rio de Janeiro State, but it presents lower intensity in this environment than on solid ground. Eucalyptus pellita wood is not infected by Scolytinae in mangrove, but Clitoria fairchildiana is highly infected by them in this biome.

In total, 25 Scolytinae species were found in the mangrove, and the xylomicetophagus species Xyleborus affinis was the most abundant either in the wood or in the traps. Wood is attractive to Xyleborus affinis just for two months after tree felling. Genus Hypothenemus is attracted by wood for five months in mangrove environment, after tree felling. The strategy adopted to capture Scolytinae in mangrove environment was more effective when impact traps were armed than in wood from recently felled trees.

\section{ACKNOWLEDGEMENT}

The authors are grateful to $\mathrm{PhD}$ Carlos Alberto Hector Flechtmann (Department of Plant Health, Rural Engineering and Soils, Universidade Estadual de São Paulo "Júlio de Mesquita Filho", Ilha Solteira campus) for the identification of Scolytinae species. 
RESUMO: Scolytinae é um grupo da Ordem Coleoptera que tem função importante na degradação da madeira em ecossistemas florestais, através da construção de galerias, facilitam a colonização por outros organismos saprófitas neste substrato, auxiliando a ciclagem de nutrientes. Nesse contexto, este trabalho teve como objetivo avaliar à ocorrência de Scolytinae na madeira de cinco espécies arbóreas expostas em ambiente de mangue, bem como realizar simultaneamente, o levantamento dos escolitíneos capturados por armadilha de impacto iscada com etanol no mesmo ambiente. O estudo foi realizado numa área de manguezal, no Bairro de Santa Cruz-RJ. Cinco toras de madeira recém abatidas de Clitoria fairchildiana, Rhyzophora mangle, Corymbia citriodora, Melia azedarach e Eucalyptus pellita, de $1 \mathrm{~m}$ e diâmetro variando $5-10 \mathrm{~cm}$, foram dispostas perpendicularmente ao solo a uma altura de $1 \mathrm{~m}$ e espaçadas de $30 \mathrm{~cm}$. Cinco armadilhas de impacto foram instaladas a uma distância de $50 \mathrm{~m}$ entre si a uma altura de $1,3 \mathrm{~m}$ em relação ao solo. Os insetos foram coletados durante o período de 5 meses. Nas madeiras, registrou-se 130 indivíduos de Scolytinae (14 espécies em 2 gêneros) cuja frequência relativa (Fr) das espécies foi: Xyleborus affinis Eichhoff (33,9\%) e Hypothenemus sp.4 (17,7\%) representando 51,6\% do total de indivíduos capturados. Hypothenemus sp.6 não foi coletada em armadilha etanólica, sendo capturada na madeira de C. fairchildiana. Em E. pellita não houve infestação. Nas armadilhas foram capturados 798 indivíduos (24 espécies em 8 gêneros), cuja a Fr de X. affinis (25,3\%) e Hypothenemus eruditus Westwood (14,5\%) representou 39,8\%.

PALAVRAS-CHAVE: Coleoptera. Xilófagos. Entomologia florestal. Mangue.

\section{REFERENCES}

ABREU, R. L. S. Estudo da ocorrência de Scolytidae e Platypodidae em madeiras da Amazônia. Acta Amazonica, v. 22, p. 413-420, 1992. https://doi.org/10.1590/1809-43921992223420

ABREU, R. L. S.; BANDEIRA, A. G. Besouros de ambrósia economicamente importantes na região de Balbina, Estado do Amazonas. Revista Árvore, v. 16, p. 346-356, 1992.

ABREU, R. L. S.; FONSECA, C. R.; MARQUES, E. M. Análise das principais espécies de Scolytidae coletadas em floresta primária no estado do Amazonas. Anais da Sociedade Entomológica do Brasil, v. 26, p. 527-535, 1997. https://doi.org/10.1590/S0301-80591997000300016

ABREU, R. L. S.; SALES-CAMPOS, C.; HANADA, R. E.; VASCONCELLOS, F. J.; FREITAS, J. A. Avaliação de danos por insetos em toras estocadas em indústrias madeireiras de Manaus, Amazonas, Brasil. Revista Árvore, v. 26, p. 789-796, 2002. https://doi.org/10.1590/S0100-67622002000600015

ANDREIV, J.; MÜLLER, J. A. A fauna como indicadora de ecossistemas florestais. In: SEMINÁRIO INTEGRADO DE INICIAÇÃO CIENTÍFICA, 4., 1998, Blumenau. Anais... Blumenau: FURB, 1998. p. 44.

BEAVER, R. A. Biological studies of Brazilian Scolytidae and Platypodidae (Coleoptera). V. The tribe Xyleborini. Journal of Applied Entomology, v. 80, p. 15-30, 1976. https://doi.org/10.1111/j.14390418.1976.tb03293.x

CARVALHO, A. G.; ROCHA, M. P.; LUNZ, A. M. Variação sazonal de Scolytidae (Coleoptera) numa comunidade de floresta natural de Seropédica, RJ. Floresta e Ambiente, v. 3, p. 9-14, 1996.

CARVAlHO, A. G. Armadilha modelo Carvalho-47. Floresta e Ambiente, v. 5, p. 225-227, 1998.

CHANDRA, A. Bioecology of wood destroying Xyleborus and their control (Insecta: Scolytidae). Indian Journal of Forestry, v. 4, p. 286-289, 1981.

COULSON, R. N.; LUND, A. E. The degradation of wood by insects. In: NICHOLAS, D. D. (Ed.). Wood deterioration and its prevention by preservative treatments. New York: Syracuse University Press, 1973. p. 277-305. 
DALL'OGLIO, O. T.; PERES FILHO, O. Levantamento e flutuação populacional de coleobrocas em plantios homogêneos de seringueira em Itiquira-MT. Scientia Forestalis , v. 51, p. 49-58, 1997.

DORVAL, A.; PERES FILHO, O.; MARQUES, E. N.; BERTI FILHO, E.; MOURA, R. G. Infestação de coleobrocas em madeiras de Eucalyptus spp. em Cuiabá, Estado de Mato Grosso. Revista de Agricultura, v. 82, p. 134-141, 2007.

DORVAL, A.; PERES FILHO, O.; MARQUES, E. N.; SOUZA, M. D. JORGE, V. C. Sazonalidade de Xyleborus ferrugineus e Xyleborus affinis (Curculionidae: Scolytinae) em savana arbórea fechada. Espacios, v. 38, p. 28-36, 2017.

FELLER, C. I.; MATHIS, W. N. Primary herbivory by Wood-boring insects along an architectural gradient of Rhizophora mangle. Biotropica, v. 29, p. 440-451, 1997. https://doi.org/10.1111/j.1744-7429.1997.tb00038.x

FINDLAY, W. P. K. Agencies of destruction. In: NIJHOFF, M.; JUNK, W. (Ed.). Preservation of timber in the tropics. Dordrecht: Junk W Publishers, 1985. p. 15-41. https://doi.org/10.1007/978-94-017-2752-5_2

FLECHTMANN, C. A. H.; COUTO, H. T. Z.; GASPARETO, C. L.; BERTI FILHO, E. Manual de pragas em florestas - Scolytidae em reflorestamentos com pinheiros tropicais. São Paulo: IPEF, 1995. 206 p.

FLECHTMANN, C. A. H.; OTTATI, A. L. T.; BERISFORD, C. W. Ambrosia and bark beetles (Scolytidae: Coleoptera) in pine and eucalypt stands in southern Brazil. Forest Ecology and Management, v. 142, p. 183191, 2001. https://doi.org/10.1016/S0378-1127(00)00349-2

FURNISS, R. L.; CAROLIN, V. M. Western forest insects. Washington: USDA, 1977. 702 p. https://doi.org/10.5962/bhl.title.131875

GERÓNIMO-TORRES, J. D. C.; PÉRES-DE LA CRUZ, M.; CRUZ-PÉRES, A. D. L.; TORRES-DE LA CRUZ, M. Scolytinae y Platypodinae (Coleoptera: Curculionidae) asociados a manglares de Tabasco, México. Revista Colombiana de Entomologia, v. 41, p. 257-261, 2015.

GONÇALVES, F. G.; CARVALHO, A. G.; CARDOSO, W. V. M.; RODRIGUES, C. S. Coleópteros broqueadores de madeira em ambiente natural de Mata Atlântica e em plantio de eucalipto. Pesquisa Florestal Brasileira, v. 34, p. 245-250, 2014. https://doi.org/10.4336/2014.pfb.34.79.499

GRAY, B. Economic Tropical Forest Entomology. Annual Review of Entomology, v. 17, p. 313- 354, 1972. JORDAL, B. H. Scolytinae Latreille, 1806. In: LESCHEN, R. A. B.; BEUTEL, R. (Ed.). Arthropoda: Insecta: Coleoptera, beetles - Morphology and systematics (Phytophaga). Berlin: DeGruyter, 2014, p. 349358. https://doi.org/10.1146/annurev.en.17.010172.001525

KÖPPEN, W. Climatologia: con un estudio de los climas de la terra. México: Fondo Cultural Económico, $1948.479 \mathrm{p}$.

KUMAR, R.; CHANDRA, A. Hetertho little or unknow males of same Indian species of Xyleborus (Scolytidae: Coleoptera). Oriental Insects, v. 11, p. 31-48, 1977.

https://doi.org/10.1080/00305316.1977.10432081

LAIDLAW, W. G.; PRENZEL, B. G.; REID, M. L.; FABRIS, S.; WIESER, H. Comparison of the Efficacy of Pheromone-Baited Traps, Pheromone-Baited Trees, and Felled Trees for the Control of Dendroctonus pseudotsugae (Coleoptera: Scolytidae). Environmental Entomology, v. 32, p. 477-483, 2003. https://doi.org/10.1603/0046-225X-32.3.477

LUNZ, A. M.; CARVALHO, A. G. Degradação da madeira de seis essências arbóreas dispostas perpendicularmente ao solo causada por Scolytidae (Coleoptera). Neotropical Entomology, v. 31, p. 351-357, 2002. https://doi.org/10.1590/S1519-566X2002000300002 
MARQUES, E. N. Índices faunísticos e grau de infestação por Scolytidae em madeira de Pinus spp. 1989. 117 f. Tese (Doutorado em Ciências Florestais) - Curso de Pós-Graduação em Engenharia Florestal, Universidade Federal do Paraná, Curitiba, 1989.

MEUER, E.; BATTIROLA, L. D.; COLPANI, D.; DORVAL, A.; MARQUES, M. I. Scolytinae (Coleoptera, Curculionidae) associados a diferentes fitofisionomias no Pantanal de Cáceres, Mato Grosso. Acta Biológica Paranaense, v. 42, p. 195-210, 2013. https://doi.org/10.5380/abpr.v42i1-4.35214

MURARI, A. B. Levantamento populacional de Scolytidae (Coleoptera) em povoamento de acácia-negra (Acacia mearnsii De Wild). 2005. 79 f. Dissertação (Mestrado em Silvicultura) - Curso de Pós-Graduação em Engenheria Florestal, Universidade Federal de Santa Maria, Rio Grande do Sul, 2005.

PEDROSA-MACEDO, J. H.; SCHÖNHERR, J. Manual dos Scolytidae nos reflorestamentos brasileiros. Curitiba: Universidade Federal do Paraná, 1985. 69 p.

PELENTIR, S. C. S. Eficiência de cinco modelos de armadilhas etanólicas na coleta de Coleoptera: Scolytidae, em floresta nativa no município de Itaara, RS. 2007. 81 f. Dissertação (Mestrado em Silvicultura) - Curso de Pós-Graduação em Engenharia Florestal, Universidade Federal de Santa Maria, Rio Grande do Sul, 2007.

PEREIRA, R. A. Scolytidae em povoamento de Pinus spp em Telêmaco Borba, PR. 2006. 51 f. Dissertação (Mestrado em Entomologia) - Curso de Pós-Graduação em Ciências Biológicas, Universidade Federal do Paraná, Curitiba, 2006.

ROCHA, J. M.; DORVAL, A.; PERES FILHO, O.; SOUZA, M. D.; COSTA, R. B. Análise da ocorrência de coleópteros em plantios de Eucaliptus camaldulensis Dehn. em Cuiabá, MT. Floresta e Ambiente, v. 18, p. 343-352, 2011. https://doi.org/10.4322/floram.2011.054

SILVA, C. A. M. Diversidade de Scolytidae (Coleoptera) em fragmentos florestais da região de Mogi Guaçu, SP. 2000. 109 f. Dissertação (Mestrado em Conservação da Natureza) - Curso de Pós-Graduação em Ciências Ambientais e Florestas, Universidade Federal Rural do Rio de Janeiro, Seropédica, 2000.

SIMEONE, J. B. Insects and wood. New York: Syracuse, 1965. 178 p.

SOUSA, W. P.; QUEK, S. P.; MITCHELL, B. J. Regeneration of Rhizophora mangle in a Caribbean mangrove forest: interacting effects of canopy disturbance and a stemboring beetle. Oecologia, v. 137, p. 436-445, 2003. https://doi.org/10.1007/s00442-003-1350-0

URAMOTO, K.; WALDER, J. M. M.; ZUCCHI, R. A. Análise Quantitativa e Distribuição de Populações de Espécies de Anastrepha (Diptera: Tephritidae) no Campus Luiz de Queiroz, Piracicaba, SP. Neotropical Entomology, v. 34, p. 33-39, 2005. https://doi.org/10.1590/S1519-566X2005000100005

WOOD, S. L. Introduced and exported american Scolytidae (Coleoptera). Great Basin Naturalist, v. 37, p. 6774, 1977.

WOOD, S. L. The bark and ambrosia beetles of North and Central America (Coleoptera: Scolytidae), a taxonomic monograph. Great Basin Naturalist Memoirs, v. 6, p. 1-1359, 1982.

WOOD, S. L. Bark and Ambrosia beetles of South America (Coleoptera: Scolytidae). Provo: Monte L. Bean Life Science Museum, 2007. 900 p. 